\title{
Challenges and Prospects of CLIL for Training Mining Engineers
}

\author{
Natalia Godzhaeva ${ }^{1}$, Timur Logunov ${ }^{1, *}$, Marina Lokteva $^{1}$, and Yulia Tochilina ${ }^{1}$ \\ ${ }^{1}$ Kemerovo State University, 650000 6, ulitsa Krasnaya, Kemerovo, Russia
}

\begin{abstract}
Increased international business contacts and mobility necessitates developing/mastering skills of communicating in a foreign language (FL) in engineering professionals, including mining engineers. However, the system of FL teaching for non-linguistic, and especially, engineering departments of the Russian higher educational institutions (HEIs) is generally inefficient. At the same time, given an insufficient level of FL skills in most content teachers, little support from their management, the lack of proper methodological training and complex linguistic learning situations, this process proves to pose considerable challenges for the existing educational setting of the Russian technical HEIs. This article summarizes the results of the expert opinion survey among Kemerovo State Technical University content and FL teachers showing a certain degree of doubt and unpreparedness in this respect. In this environment, the authors suggest that the optimal solution would be a gradual introduction of CLIL elements with a focus on more elaborated preparatory techniques. The study assumes the need for forming a specific support system provided by language teachers to boost learners' linguistic confidence prior to students' participation in CLIL format courses.
\end{abstract}

\section{Introduction}

Since the turn of the century, higher education in Russia has seen many innovative changes, including in the specific field of teaching foreign languages. Russia's labour market has become more competitive, its structure is also changing: the need for highly qualified experts with flexible and adaptable skills and abilities has increased and only the most competent graduates will benefit from the situation.

Given the process of globalization and intense foreign contacts in various spheres of life, knowledge of a foreign language is regarded either as a prerequisite for applicants' employment or a valuable asset alongside specific professional competences. The internationalization of Russia's education system in the post-Bologna period and the ensuing paradigm shift towards a competence-based approach caused profound changes in education.

The above trends in the Russian education system call for switching to the new forms of instructions to meet the demand of real-life needs in the chosen field.

\footnotetext{
* Corresponding author: tlogunov@mail.ru
} 


\section{Materials and Methods}

More than a decade ago, the British Council in partnership with the Ministry of Education of the Russian Federation carried out a survey, which findings were far from optimistic: university English courses did not equip students with adequate communication skills for future work or future study [1].

In this context, foreign language competence for engineering students is considered to be particularly essential in contemporary conditions when solving professional problems requires mastering most recent international technological advances and research results. However, one has to admit there is a common mismatch between the intended results and actual training outcomes/achievements. In many Russian universities English is usually taught for students of non-linguistic specialties during the 1 st and 2 nd years of studying. In fact, the restricted amount of English classes at nonlinguistic universities only increases the necessity for teaching professionally oriented English in order to develop all the necessary English communication skills and competences as well as to reach the target level B2, which is specified as the standard for the Bachelor's degree. Therefore, by the time of graduation, students have mastered the language of their field in the level insufficient for productive and effective professional communication and have lost previously acquired communicative skills without constant practice, which prevents successful development of professionals [2].

Therefore, implementing an integrated professional foreign language course (a CLIL course) for the students of Mining Engineering Institute of Kuzbass State Technical University (KuzSTU) seems to be particularly important. Firstly, to communicate in one's professional field effectively one should keep mastering his or her foreign language skills regularly. Secondly, some mining professionals have to change their specialization area due to some economic and social processes. So, they should be trained flexibility in developing their professional foreign language skills and competences, in adapting their vocabulary and structures to using in a particular professional area. Thirdly, foreign language level of many graduates in Russia leaves much to be desired.

With regard to the common European standards developed by the Council of Europe to harmonize the aims and content of teaching foreign languages, they link the tasks of forming students' foreign language competence with their professional activities [3]. Thus, the European approach dictates the use of professional standards as the main source of the requirements for the language competence of a university graduate.

The analysis made it possible to identify the following requirements for foreign language competence of specialists, contained in the requirements for knowledge and skills for certain labour functions.

Table 1. The requirements of Professional Standards for Engineering and technical field in foreign language.

\begin{tabular}{|c|c|c|}
\hline Profession & Knowledge & Skills \\
\hline Engineering & $\begin{array}{l}\text { - Technical English is necessary to } \\
\text { interact and obtain information } \\
\text { from foreign sources; } \\
\text { - English language is essential for } \\
\text { interaction and coordination of the } \\
\text { developed design documentation } \\
\text { with representatives of foreign } \\
\text { customers and related } \\
\text { organizations; } \\
\text { - technical characteristics and } \\
\text { economic indicators of domestic } \\
\text { and foreign developments in the }\end{array}$ & $\begin{array}{l}\text { - To analyze technical literature in } \\
\text { Russian and English; } \\
\text { - to master modern domestic and } \\
\text { foreign software packages when } \\
\text { solving circuit, system and } \\
\text { network tasks; } \\
\text { - to collect and analyze scientific } \\
\text { and technical information, to } \\
\text { generalize domestic and foreign } \\
\text { experience in the field of radio }\end{array}$ \\
\hline
\end{tabular}




\begin{tabular}{|l|l|l|}
\hline & field of radio electronic equipment. & $\begin{array}{l}\text { engineering, to conduct analysis } \\
\text { of patent literature. }\end{array}$ \\
\hline
\end{tabular}

As Table 1 shows, the requirements for mastering a foreign language are totally lacking. However, a more careful analysis of these standards reveals that a number of the "knowledge" and "skills" indicated in them, apparently, require the use of a foreign language. Moreover, the following standard does not have direct requirements for the spoken level of foreign language proficiency.

There are a number of challenges for efficient training both general foreign language and professional foreign language in polytechnic universities. Firstly, the professional standards for the mining professionals contain no requirements for foreign language competence. Thus, the question arises should a mining engineer be able to translate specialized technical literature for imported technical means (machines, apparatus, instruments, software programs, etc.)? As practice shows, the quality of such translations fulfilled by unprofessional interpreters does not always match their purpose. "In the case of technically complex products, it's not just about translating, notes A.V. Kuznetsov, but about a competent and unambiguous transfer of meaning, deprived of the ability to violate the restrictions on installation and safe use." [4]

Secondly, limited FL competence of the mining engineer's and professionals specialist's often prevent them from understanding the meaning of technical texts. Is a mediocre technical translator sufficient for a modern language level engineer? Is it right to expect that in the conditions of globalization and universal communication the probability of direct communication of the engineer and mining specialist (in electronic or oral form) with foreign colleagues in a foreign language will be so insignificant that it should be neglected?

Thirdly, there is an essential issue of motivation. As many studies show, the question "Why do you learn English?" is one of the most difficult for students themselves [5]. According to I.E. Abramova et al., (Petrozavodsk State University), most students believe that they will need a foreign language only during tourist trips. Most students "have no motivation for studying a foreign language for communication in the professional sphere" [6]

According to A.A. Kaskevich (Siberian State Technological University), students of a technical college learn a foreign language without experiencing the need and satisfaction from the process of knowledge. $61.86 \%$ of students of a technical college "consider that, in comparison with other academic disciplines, a foreign language is the most complex subject. $45.36 \%$ of students are forced to study the language, because they "need", $71 \%$ do not want to go to classes" [7].

Thus, when studying a foreign language, students experience a "language barrier" (a barrier of language anxiety [8], and this barrier is largely motivational. " $34.02 \%$ of students experience a high level of language barrier, $54.64 \%$ of respondents showed an average level and only $11.34 \%$ of students showed a low level of the language barrier, which is due to the lack of a natural foreign environment and low level of motivation" [7].

Students of mining engineering and technical profile do not have a bright, interesting and at the same time pragmatically useful perspective, which would motivate them to study a foreign language. The study of the language, limited by the function of "technical translation", is not such a prospect. I.E. Abramova formulate this as follows: "The main problem in teaching a foreign language in classroom conditions is that the emphasis in

The beneficial features of the CLIL approach include its ability to activate thought processes, connecting the cognitive level of perception and information processing, which implies not only understanding the latter, but also its analysis, comparison and conclusions. Stimulation of the processes occurs due to "working and living" content, information is used "here and now", quick response is required, the process of transcoding information 
turns into a process of its perception and dealing with it. All this makes the work of memory and thought processes more intensive, so that knowledge becomes stronger and more orderly. The principle of unity of thought and speech activity in a FL, expressed in cognitive load, is a key element of CLIL [9].

Currently, the implementation of CLIL in the Russian higher school is episodic. At the same time, the management of universities understands that in the conditions of increasing globalization, the transformation of information into a subject and product of labour, the creation of a multi-national model of the economy is inevitable, where production and market success directly depends on the ability of specialists to effective information exchange and other forms of functioning in the environment, in which foreign-language communicative competence is in demand [10].

In the new educational paradigm, a foreign language ceased to be an additional competence and is considered to be not only a means of transmitting information, but also a means of obtaining it, which makes education global and integrated in terms of the exchange of scientific knowledge and interdisciplinary training.

We consider Content and Language Integrated Learning (CLIL) to be the most appropriate approach for developing a particular kind of foreign language required by engineering students.

Among researchers there is no consensus on how to organize CLIL-learning without losses for substantive knowledge [11].

In our time CLIL is implemented by three models:

- language training separately and in advance, as preparation for the study of the subject in the language;

- learning a foreign language through the subject content, which has already been studied in the native language;

- the study of the language and the subject in one course [12].

The latter model is more consistent with the CLIL disciple, but so far it has rarely been practiced in its pure form, since the existing conditions and the traditional organization of the educational process in universities do not allow this.

Despite the active research in the field of CLIL and its increasing popularity among teachers and students, there is still no single concept in the pedagogical practice regarding the use of this approach to solve the problems of FL teaching.

To meet the above challenges many teachers in Russian universities are adapting methodologies to adjust their teaching practices in such a way that they motivate and engage students while reaching language standards. In this way, developing and introducing CLIL courses into the educational process can be a beneficial factor to intensify and improve the process of mastering a foreign language.

\section{Results and Discussion}

In present article we use the case of a Russian university, Kemerovo State Technical University, to illustrate the attitude of teachers towards teaching some subjects in foreign language and the ways of integrating subject and language competencies in Bachelor's courses at KuzSTU.

The method employed in our research was a descriptive survey. The data were collected by means of questionnaire. The questionnaire was specially designed to collect the information about teachers' expert opinions regarding teaching a special discipline in a foreign language to the Bachelor students of the Institute of Mining Engineering of KuzSTU, the difficulties in preparing and delivering CLIL courses and the ways of overcoming them. 
The project participants included a group of content teachers and foreign language teachers. They took part in the experimental pilot survey held. Teachers' opinions were summarized afterwards and analyzed in terms of teachers' attitudes, doubts and hopes connected with challenges and prospects of teaching content in FL. Thus, the discussed research is focused primarily on analyzing the associated challenges and possible strengths and weaknesses of the introduction of CLIL format studies in the first FL (English).

Another consideration to bear in mind pertains to the professional training teachers receive. CLIL requires subject teachers with foreign language skills and vice versa, unfortunately, this requirement cannot be met by the majority of the educators.

The last but not the least circumstance to take into account is the diversity of curriculums. CLIL appears as a very interesting proposal to promote interdisciplinary curriculum or co-teaching. However, this approach is difficult to implement due to the fact that some subject teachers are not even basically prepared in a foreign language. One option to tackle this issue would be co-teaching by having language teachers reading some modules of certain subjects in the curricula.

We conducted teachers' pilot survey which clearly demonstrates teachers' attitudes toward CLIL (the survey results are summarized in Tables 2 and 3).

Table 2. The results of surveying teachers' attitudes toward CLIL (total number of respondents is given in brackets)

\begin{tabular}{|c|c|c|c|c|}
\hline \multicolumn{2}{|c|}{$\begin{array}{l}\text { Selected questions } \\
\text { (reformulated for the purpose of the } \\
\text { research analysis) }\end{array}$} & \multirow{2}{*}{$\begin{array}{c}\begin{array}{c}\text { Content } \\
\text { teachers (18) }\end{array} \\
2\end{array}$} & \multirow{2}{*}{$\begin{array}{c}\begin{array}{c}\text { FL } \\
\text { teachers } \\
(\mathbf{1 1})\end{array} \\
4\end{array}$} & \multirow{2}{*}{$\begin{array}{c}\begin{array}{c}\text { Total for } \\
\text { the survey } \\
(29)\end{array} \\
6\end{array}$} \\
\hline & very necessary & & & \\
\hline teaching major & quite necessary & 8 & 6 & 14 \\
\hline subjects in FL & not necessary & 8 & 1 & 9 \\
\hline \multirow{4}{*}{$\begin{array}{l}\text { CLIL courses are } \\
\text { to be taught by } \\
\text { (multiple options } \\
\text { were possible): }\end{array}$} & FL teachers & 1 & 2 & 2 \\
\hline & content teachers & 3 & 2 & 5 \\
\hline & jointly & 8 & 6 & 14 \\
\hline & foreign professionals & 7 & $\overline{1}$ & 8 \\
\hline \multirow{4}{*}{$\begin{array}{l}\text { CLIL courses } \\
\text { could increase } \\
\text { motivation for } \\
\text { studying content } \\
\text { courses in FL }\end{array}$} & very necessary & 3 & 3 & 6 \\
\hline & quite necessary & 10 & 5 & 15 \\
\hline & rather not & 1 & 2 & 3 \\
\hline & definitely not & 4 & 1 & 5 \\
\hline \multirow{4}{*}{$\begin{array}{l}\text { CLIL courses can } \\
\text { help for students } \\
\text { be more } \\
\text { competitive in } \\
\text { labour market }\end{array}$} & very necessary & 7 & 4 & 11 \\
\hline & quite necessary & 5 & 3 & 8 \\
\hline & rather not & 2 & 1 & 3 \\
\hline & definitely not & 4 & 3 & 7 \\
\hline \multirow{2}{*}{$\begin{array}{l}\text { Your } \\
\text { expectations from } \\
\text { CLIL courses }\end{array}$} & $\begin{array}{l}\text { Encouraging students } \\
\text { reading more literature } \\
\text { in FL }\end{array}$ & 9 & 4 & 13 \\
\hline & $\begin{array}{l}\text { Developing professional } \\
\text { skills }\end{array}$ & 8 & 4 & 12 \\
\hline
\end{tabular}


Table 3. Areas positively and negatively affected by CLIL.

\begin{tabular}{|l|c|l|c|}
\hline \multicolumn{1}{|c|}{ POSITIVES } & $\begin{array}{c}\text { Number } \\
\text { of } \\
\text { responses }\end{array}$ & \multicolumn{1}{|c|}{ NEGATIVES } & $\begin{array}{c}\text { Number of } \\
\text { responses }\end{array}$ \\
\hline $\begin{array}{l}\text { Students' motivation to } \\
\text { learn FL, learn and practice } \\
\text { FL in real context }\end{array}$ & 17 & $\begin{array}{l}\text { Demanding preparation } \\
\text { for teachers and students }\end{array}$ & 24 \\
\hline $\begin{array}{l}\text { Encouraging method in } \\
\text { learning special disciplines }\end{array}$ & 16 & $\begin{array}{l}\text { Extending the period of } \\
\text { studying one module }\end{array}$ & 13 \\
\hline $\begin{array}{l}\text { Developing foreign } \\
\text { language communicative } \\
\text { competence }\end{array}$ & 19 & $\begin{array}{l}\text { Possible decrease in the } \\
\text { content subject learning } \\
\text { outcomes }\end{array}$ & 8 \\
\hline
\end{tabular}

The results of teachers' survey were collected and analyzed. Totally, 10 content teachers were sure or quite sure that courses taught in FL are necessary in their curriculum. Strictly negative responses to this question were given by 8 content teachers. FL teachers, on average, demonstrated more positive, though somewhat reserved, attitude to CLIL format of teaching content subjects. What is more, their acceptance of this prospect is proved with repeatedly positive proportion of their response to all the questions.

As we can see from Table 2 and 3 a large number of teachers believe that such courses and the format of classes should be taught at KuzSTU by invited specialists (preferably foreign ones). However, a large number of teachers are sure that teaching courses in FL can be organized jointly by FL and content teachers, which seems logical and realistic and a good understanding of the ways to overcome the possible difficulties. It implies a high degree of unpreparedness and lack of confidence among content teachers for introducing integrated training at the current stage.

On the other hand, the results of survey also assume an expected increase in students' motivation for studying content courses in FL and having chances to be more confident and competitive in labour market.

Successful implementation of CLIL format depends on a variety of factors. Lack or insufficient development of any of them may impede wider CLIL implementation in KuzSTU. Statistical data prove the fact that only the brightest students can really make full use of all the linguistic input provided by a native speaker whereas about $70 \%$ of student respondents would prefer to have a bi-lingual local subject teacher who, in case there is a need, could clarify the most complicated issues or murky areas with the help of the mother tongue. Another concern is the language level required from teachers working through the medium of a foreign language. What benchmark do we need here to assess it? In our view, it should be functionally adequate for teaching the subject in the classroom, somewhere $\mathrm{B} 2+$, which is rather challenging for an average lecturer.

Our analysis showed that it is not possible to significantly influence the national higher education system at present. However, the local changes in higher education of regional Russian universities are quite real. These changes can include demotivation of the use of a foreign language, the lack of new techniques, as well as strictly regulated activity of universities. Individual small CLIL modules can be a form of learning in the early stages of the course, which will be adequately perceived by students and will be a feasible task for the teacher.

\section{Conclusion}

Taking into consideration the existing challenges and survey results discussed above, today we can still witness that demand for foreign language competence for non-linguistic 
specialists is increasing and expanding. Learners need new courses matching their ever growing needs and requirements resulting from what the labour market demands. Learning FL in the framework of CLIL helps students to develop the specific way of thinking and to be ready to perform their professional duties and responsibilities. On the other hand, it makes teaching foreign language more meaningful and effective.

The modern University should allocate resources to attract foreign specialists, creating the prerequisites for the development of University language environment and motivating students to communicate in a foreign language effectively. Organizational measures such as the tandem "language teacher - content teacher" will help to solve the problem of personnel shortage, as it will strengthen the interdisciplinary component of the educational process as a whole. The proposed measures are recommendations that are desirable to be taken into account in considering the ways and forms of modernization of educational processes at the University.

\section{References}

1. N. A. Zinkevich, B. L. Ivanova, The Magic of Innovations. New Techniques and Technologies in Teaching Foreign Languages (CU, Cambridge 2015)

2. T. A. Logunov, M. S. Lymareva, Bulletin of Kemerovo State University, 3, 187-192 (2017)

3. T. A. Tantsura, Contemporary Issues of Science and Education (KemSU, Kemerovo, 2015)

4. A. V. Kuznetsov, Human Dimension of Global Economy and Politics (MSU, Moscow, 2013)

5. N. Godzhaeva, T. Logunov, Journal of Siberian Federal University. Humanities \& Social Sciences, 8:11, 2299-2306 (2015)

6. I. E. Abramova, A. V. Ananyina, E. P. Shishmolina, Bulletin of the Humanities Faculty of Ivanovo State Chemical Technological University, 6, 110-113 (2014)

7. A. A. Kaskevich, Bulletin of Krasnoyarsk State Agrarian University, 11, 256-259 (2012)

8. A. E. Krasheninnikova, Modern Trends in Foreign Language teaching in NonLinguistic University, 8, 53-56 (2014)

9. P. Mehisto, D. Marsh, Uncovering CLIL: Content and Language Integrated Learning in Bilingual and Multilingual Education (Macmillan, Oxford, 2008)

10. I. I. Filippovich, Research Bulletin of Southern Institute of Management. Linguistics, 4, 74-78 (2015)

11. D. Lasagabaster, J. Sierra, ELT Journal, 64:4, 367-375 (2009)

12. S. Lucietto, International CLIL Research Journal, 1:1, 83-32 (2008) 